\title{
KONSUMSI OBAT HERBAL PADA PASIEN KANKER PAYUDARA DI RUMAH SAKIT UMUM DAERAH MARGONO SOEKARJO
}

\author{
Khamidah Achyar \\ Email: khamidahachyar30@gmail.com \\ Program Studi Kebidanan DIII Fakultas Ilmu Kesehatan, Universitas Muhammadiyah Purwokerto. \\ Jl. Supardjo Rustam Km.7 POBOX 229 Purwokerto 53181 Telp. (0281)6844253
}

\begin{abstract}
Abstrak
Berdasarkan Riskesdas tahun 2010 masyarakat Indonesia mengkonsumsi jamu gendong sebesar 55,3\%. Jenis jamu gendong yang biasa dikonsumsi yaitu kunyit asem (65\%) dan 63\% konsumen mengkonsumsi jamu gendong untuk memelihara kesehatan. Kurkumin berguna untuk terapi sinergis kanker payudara dalam mengurangi toksisitas terkait dengan penggunaan obat-obatan. Berdasarkan Riskesdas tahun 2013 jumlah penderita kanker 347.792 orang. Jumlah penderita kanker di Provinsi Jawa Tengah tahun 2013 sekitar 68.638 orang.

Penelitian ini bertujuan untuk mengetahui gambaran penggunaan obat herbal pada pasien kanker payudara di Rumah Sakit Margono Soekarjo Purwokerto. Desain penelitian ini menggunakan cross sectional dengan jumlah responden sebanyak 30 orang.

Hasil penelitian iniyaitu umur responden diatas 40 tahun sebanyak 90\%. Pendidikan terakhir paling rendah tidak sekolah yaitu 23,3\%, paling banyak Sekolah Dasar 56,7\%. Responden yang menggunakan obat herbal sebanyak $80 \%$ dan jenis obat herbal yang dikonsumsi yaitu obat tradisional, jamu rebusan daun-daunan dan rimpang-rimpangan sebanyak $90 \%$. Sumber informasi penggunaan obat tradisional berasal dari adat kebiasaan turun temurun nenek moyang sebanyak $90 \%$.
\end{abstract}

Simpulan: konsumsi obat herbal pada penderita kanker payudara berdasarkan adat kebiasaan masyarakat.

Kata Kunci:Budaya, Kanker payudara, Herbal

\section{Pendahuluan}

Penyakit degenerative terbanyak menyerang pada wanita adalah penyakit kanker payudara. Pada umumnya penyakit tersebut diketahui setelah stadium lanjut, ketika dokter memvonis tidak mampu mengobati karena sudah terjadi metastasis. Kejadian hal tersebut banyak menimpa wanita usia produktif pada umumnya. Salah satu faktor penyebab penderita tidak segera berobat dikarenakan tidak adanya gejala yang dirasakan sakit secara signifikan. Secara angka Nasional berdasarkan Riskesdas tahun 2013 jumlah penderita kanker 347.792 orang. Jumlah penderita kanker di Provinsi Jawa Tengah tahun 2013 sekitar 68.638 orang. Faktor risiko yang menyebabkan kanker payudara yaitu faktor genetik, hormonal, nutrisional, morfologik dan radiasi. 
Secara umum masyarakat akan mencari pengobatan setelah gejala penyakit semakin parah. Pengobatan yang dilakukan biasanya pengobatan herbal/tradisional, modern dan keduanya. Berdasarkan Riskesdas tahun 2010 masyarakat Indonesia mengkonsumsi jamu gendong sebesar 55,3\%. Hasil penelitian Aria M.G.N(2008) bahwa Jenis jamu gendong yang biasa dikonsumsi adalah kunyit asem (65\%) dan 63\% konsumen mengkonsumsi jamu gendong dengan alasan untuk memelihara kesehatan.

Berdasarkan hasil penelitian Quispe-Soto ET,et.al (2016), kurkumin mungkin cukup bernilai dalam terapi sinergis kanker payudara yang mengurangi toksisitas terkait dengan penggunaan obat-obatan. Demikian juga menurut Banik U,et.al (2017), Kurkumin memodulasi karsinogenesis payudara melalui pengaruhnya terhadap siklus sel dan proliferasi, apoptosis, penuaan, penyebaran kanker dan angiogenesis. Menurut Zheng J, et.al(2016),beberapa rempah merupakan sumber potensial untuk pencegahan dan pengobatan kanker, seperti Curcuma longa (tumeric), Nigella sativa (jintan hitam), Zingiber officinale (jahe), Allium sativum (bawang putih), Crocus sativus (safron), Piper nigrum (lada hitam ) dan Capsicum annum (cabai), yang mengandung beberapa senyawa bioaktif penting, seperti curcumin, thymoquinone, piperine dan capsaicin.

Obat herbal yang bermanfaat untuk kanker payudara selain kunyit yaitu sirsak dan kulit manggis. Berdasarkan hasil penelitian Syed Najmuddin SU,et.al (2016); George VC (2012) bahwa daun sirsak merupakan obat kanker payudara, kandungan yang terdapat pada daun sirsak dapat menekan sel tumor, mengurangi ukuran dan berat tumor serta meningkatkan sel darah putih, sel T. Berdasarkan hasil penelitian Prabhakaran K, et.al (2016) Annona muricata (sirsak), dapat menghambat sel kanker payudara sebesar 98\%. Menurut Foster K, et.al(2017), bahwa sebagian besar penggunaan daun sirsak pasien kanker Jamaika $(80,80 \%)$ menggunakan tanaman obat dalam praktik pengobatan sendiri. Kebiasaan seperti itu tidak tergantung pada pendidikan orang, status ekonomi dan lebih tinggi pada kelompok usia 55-74 dibandingkan dengan pasien yang lebih muda. Penggunaan ramuan bergantung pada selera tradisi pasien dan perspektif khasiat herbal.

\section{Metode Penelitian}

Desain dalam penelitian ini menggunakan cross sectional. Populasi penelitian ini yaitu pasien wanita yang didiagnosis kanker payudara di Rumah Sakit Margono Soekarjo. Peneliti dengan menggunakan kuesioner mewawancarai responden dengan melibatkan mahasiswa kebidanan yang sedang praktik klinik selama dua bulan, Mei-Juli 2018, dengan jumlah sampel 30 orang. 


\section{Hasil dan Pembahasan}

a. Hasil

Responden dalam penelitian ini berjumlah 30 orang. Hasil penelitian tentang diuraikan berdasarkan tabelberikut:

3.1 Distribusi Frekuensi Usia Responden

\begin{tabular}{|c|c|c|}
\hline Usia & Jumlah & $\%$ \\
\hline$\leq 40$ & 3 & 10 \\
\hline$>40$ & 27 & 90 \\
\hline Total & 30 & 100 \\
\hline
\end{tabular}

Berdasarkan table 3.1 bahwa usia responden terbanyak lebih dari 40 tahun (90\%).

\subsection{Distribusi Frekuensi Pendidikan} Responden

\begin{tabular}{ccc}
\hline Pendidikan & Jumlah & $\mathbf{\%}$ \\
\hline Tidak Sekolah & 7 & 23,3 \\
SD & 17 & 56,7 \\
SMP & 3 & 10 \\
SMA & 3 & 10 \\
Total & 30 & 100 \\
\hline
\end{tabular}

Berdasarkan table 3.2 distribusi frekuensi responden pendidikan terbanyak yaitu SD (56,7\%).

\subsection{Distribusi Frekuensi Paritas \\ Responden}

Berdasarkan table 3.3 distribusi frekuensi paritas responden terbanyak yaitu lebih dari 3 $(56,7 \%)$.

\subsection{Distribusi Frekuensi Gejala Kanker}

\section{Payudara}

\begin{tabular}{ccc}
\hline Gejala & Jumlah & $\mathbf{\%}$ \\
\hline Tidak ada & 0 & 0 \\
Ada & 30 & 100 \\
Total & 30 & 100 \\
\hline
\end{tabular}

Berdasarkan table 3.4 distribusi frekuensi gejala kanker payudara, semua responden mengalami gejala yang dirasakan (100\%).

3.6 Distribusi Frekuensi Lama Gejala Kanker Payudara

\begin{tabular}{ccc}
\hline $\begin{array}{c}\text { Lama } \\
\text { Gejala }\end{array}$ & Jumlah & $\%$ \\
\hline$<1$ tahun & 8 & 26,7 \\
$\geq 1$ tahun & 22 & 73,3 \\
Total & 30 & 100 \\
\hline
\end{tabular}

Berdasarkan table 5.1 .7 distribusi frekuensi lama gejala kanker payudara terbayak lebih dari 1 tahun (73,3\%).

3.7 Distribusi Frekuensi Penggunaan obat Herbal

\begin{tabular}{ccc}
\hline $\begin{array}{c}\text { Penggunaan } \\
\text { Obat Herbal }\end{array}$ & Jumlah & \% \\
\hline Ya & 24 & 80 \\
Tidak & 6 & 20 \\
Total & 30 & 100 \\
\hline
\end{tabular}

Berdasarkan table 3.6 distribusi frekuensi penggunaan obat herbal sebanyak $80 \%$.

\begin{tabular}{ccc}
\hline Paritas & Jumlah & $\%$ \\
\hline$<3$ & 13 & 43,3 \\
$\geq 3$ & 17 & 56,7 \\
Total & 30 & 100 \\
\hline
\end{tabular}

3.8 Distribusi Frekuensi Sumber Informasi Obat Herbal

\begin{tabular}{lll}
\hline $\begin{array}{l}\text { Sumber } \\
\text { Informasi }\end{array}$ & Jumlah & $\mathbf{\%}$ \\
\hline Turun & 27 & 90 \\
temurun & 3 & 10 \\
Media & & \\
Total & 30 & 100 \\
\hline
\end{tabular}


Berdasarkan table 3.7 distribusi frekuensi sumber informasi obat herbal paling banyak diperoleh dari nenek moyang turun temurun $90 \%$.

3.9 Distribusi Frekuensi Jenis Obat Herbal yang di konsumsi

\begin{tabular}{ccc}
\hline $\begin{array}{c}\text { Jenis Obat Herbal } \\
\text { yang di konsumsi }\end{array}$ & Jumlah & $\mathbf{\%}$ \\
\hline Kemasan Produk & 3 & 10 \\
Tradisional & 27 & 90 \\
Total & 30 & 100 \\
\hline
\end{tabular}

Berdasarkan table 3.8 distribusi frekuensi jenis obat herbal yang dikonsumsi yaitu ramuan tradisional sebanyak $90 \%$.

b. Pembahasan

Karakteristik responden dari hasil penelitian ini meliputi umur, pendidikan, dan paritas. Umur responden berdasarkan hasil penelitian ini sebagian besar diatas 40 tahun, sebanyak 27 orang (90\%). Berdasarkan hasil penelitian Dwisatyadini M., Usia warga yang menderita penyakit degeneratif $27 \%$ (8 dari 30 responden) pada usia 17-30 tahun, 40\% (12 dari 30 responden) pada usia 31-50 tahun, 33\% (10 dari 30 responden) pada usia lebih dari 51 tahun, 40\% usia 31-50 tahun responden telah menderita penyakit degeneratif. Berdasarkan penelitian Dameri, et.al, wanita berusia di bawah 50 tahun.
Pendidikan terakhir responden dari hasil penelitian ini paling rendah tidak sekolah yaitu 7 orang (23,3\%), paling banyak Sekolah Dasar (SD) yaitu 17 orang $(56,7 \%)$ dan paling tinggi Sekolah Menengah Atas (SMA) sebanyak 3 orang $10 \%)$.

Karakteristik responden riwayat persalinan (paritas) dari hasil penelitian ini yaitu seluruh responden yang belum mempunyai riwayat persalinan ada 4 orang dan 26 responden terdiri dari paritas kurang dari 3 sebanyak 9 orang dan 17 orang responden dengan paritas lebih dari 3 kali. Responden yang menjadi akseptor KB dari hasil penelitian ini menggunakan kontrasepsi hormonal sebanyak 17 orang, dengan lama KB paling banyak kurang dari 5 tahun sebanyak 20 orang $(66,7 \%)$.

Hasil penelitian ini semua responden mengalami dan merasakan adanya gejala kanker payudara, dengan ditandai adanya benjolan kecil di payudaranya. Gejala ini dirasakan lamanya lebih dari 1 tahun sebanyak 22 orang $(73,3 \%)$. Berdasarkan penelitian Hasanah SN, jenis tumor/kanker terbanyak ditemukan organ payudara (32\%). Dari 71 pasien tumor/kanker, $80,3 \%$ menerima terapi jamu; $14,1 \%$ menerima terapi kesehatan konvensional dan jamu; 2,8\% menerima terapi konvensional jamu dan kesehatan tradisional; $1,4 \%$ menerima terapi jamu dan kesehatan tradisional. 
Menurut penelitian Sayed S.,et.al bahwa dari mereka, $56 \%$ tahu gejala dan tanda-tanda kanker payudara, 44\% tahu bagaimana kanker payudara didiagnosis, $37 \%$ melakukan pemeriksaan payudara sendiri secara teratur, dan $7 \%$ memiliki mammogram atau USG payudara pada tahun lalu. Sebanyak 23\% sebelumnya telah memperhatikan benjolan di payudara mereka. Sebanyak 14\% memiliki abnormal CBEs.

Hasil penelitian ini yang mempuyai riwayat tumor sebelumnya sebanyak 3 responden (10\%). Senada dengan hasil penelitian Sackey H., et.al bahwa yang memiliki riwayat keluarga kanker payudara meningkatkan risiko kanker payudara invasif kontralateral hampir 50\% (rasio tingkat kejadian 1,5 (95\% CI 1,0$2,0)$ ). Wanita di bawah empat puluh tahun saat diagnosis, tanpa riwayat keluarga, memiliki peningkatan risiko 7 kali lipat, dan mereka yang memiliki riwayat keluarga memiliki peningkatan risiko 14 kali lipat untuk kanker payudara invasif berikutnya dengan SIRs dari 7,2 dan 14,3, masing-masing. Keseluruhan risiko kematian pada wanita dengan kanker payudara in situ adalah meningkat secara signifikan sebesar $30 \%$ dibandingkan dengan populasi umum tetapi sangat tergantung pada kejadian tersebut dari kejadian kanker invasif kedua.
Penggunaan obat herbal pada pasien kanker payudara berdasarkan hasil penelitian ini sebanyak 24 orang responden $(80 \%)$. Jenis obat herbal yang dikonsumsi sebanyak 27 responden $(90 \%)$ yaitu menkonsumsi jamu tradisional, hasil rebusan (daun sirsak, kulit manggis, dan temu-temuan). Berdasarkan hasil penelitian Damery, et.al bahwa prevalensi penggunaan obat herbal adalah 19,7\%. Pengguna lebih cenderung makmur, wanita, dan berusia di bawah 50 tahun. Berdasarkan penelitian Shim, et.al, Jamu Jepang diintegrasikan ke dalam sistem medis nasional yang paling dan herbal Amerika obat yang paling sedikit; Akupunktur Amerika dan akupunktur Jepang jatuh di tengah. Hasil pengobatan adalah yang paling menguntungkan untuk jamu Jepang dan yang paling tidak menguntungkan untuk jamu Amerika.

Berdasarkan penelitian Fritz H., et.al bahwa melaporkan kemanjuran kedelai untuk hot flash, menunjukkan tidak ada penurunan yang signifikan dalam hot flashes dibandingkan dengan plasebo. Tidak ada bukti yang menunjukkan bahaya dari penggunaan kedelai sehubungan dengan risiko kanker payudara atau kekambuhan, berdasarkan data observasi jangka panjang. Asupan kedelai konsisten dengan diet tradisional Jepang (2-3 porsi harian, mengandung 25-50 mg isoflavon) 
dapat melindungi terhadap kanker payudara dan kekambuhan.

Hasil penelitian ini sumber informasi obat herbal terbanyak berasal dari turun temurun/nenek moyang sebanyak 27 orang (90\%). Hal ini kemungkinan disebabkan oleh sebagian responden berpendidikan rendah dan mengandalkan informasi serta kepercayaan dari orang tua yang diturunkan secara turun temurun. Hal ini sejalan dengan hasil penelitian Panganai T\& Shumba bahwa wanita, mengaku menggunakan herbal, dipilih secara sengaja dari bangsal persalinan dan pasca kelahiran. terutama kotoran gajah. Para wanita tidak memiliki pengetahuan tentang bagaimana zat bekerja tetapi percaya pada mereka, karena mereka dapat bertahan dalam perjalanan waktu.

Petugas kesehatan, baik dokter bidan maupun perawat dirumah sakit belum interest memberikan informasi terhadap penggunaan obat herbal yang aman. Sejalan berdasarkan penelitian Christina J., et.al., bahwa Mayoritas penelitian menyelidiki pengetahuan perawat dan sikap terhadap penggunaan CTs untuk onkologi dilakukan di negara maju. Secara keseluruhan, itu diidentifikasi bahwa perawat perlu meningkatkan pengetahuan mereka dan keterampilan tentang CT sehingga mereka lebih percaya diri untuk membantu pasien dalam mengintegrasikan pengobatan konvensional dan CT untuk manajemen kanker.berbeda dengan hasil penelitian Shim di Jepang bahwa laporan obat herbal yang dilakukan di Jepang atau AS terdaftar di Perpustakaan Cochrane.

\section{Kesimpulan}

Responden yang menggunakan obat herbal informasinya berasal dari orang tua secara turun temurun. Jenis obat herbal yang dikonsumsi adalah obat tradisional, jamu/daun.

\section{Daftar Pustaka}

[1] Quispe-Soto ET, Calaf GM. Effect of curcumin and paclitaxel on breast carcinogenesis. Int J Oncol. 2016 Dec;49(6):2569-2577.

[2] Banik U, Parasuraman S, Adhikary AK, Othman NH. Curcumin: The Spicy Modulator Of Breast Carcinogenesis. J Exp Clin Cancer Res. 2017 Jul 19;36(1):98.

[3] Syed Najmuddin SU, Romli MF, Hamid M, Alitheen NB, Nik Abd Rahman NM. Anticancer effect of Annona Muricata Linn Leaves Crude Extract (AMCE) on breast cancer cell line. BMC Complement Altern Med. 2016 Aug 24;16(1):311

[4] Zheng J, Zhou Y, Li Y, Xu DP, Li S, Li HB. Spices For Prevention And Treatment Of Cancers.Nutrients. 2016 Aug 12;8(8).

[5] George VC, Kumar DR, Rajkumar V, Suresh PK, Kumar RA. Quantitative Assessment Of The Relative Antineoplastic Potential Of The $N$-Butanolic Leaf Extract Of Annona Muricata Linn. In Normal And Immortalized Human Cell Lines. Asian Pac J Cancer Prev. 2012;13(2):699-704.

[6] Prabhakaran K, Ramasamy G, Doraisamy U, Mannu J, K R, Murugesan JR. Polyketide Natural Products, Acetogenins from Graviola (Annona muricata L), its Biochemical, Cytotoxic Activity and Various Analyses Through Computational and Bio- 
Programming Methods. Curr Pharm Des. 2016;22(34):5204-5210.

[7] Foster K, Younger N, Aiken W, Brady-West D, Delgoda R. Reliance On Medicinal Plant Therapy Among Cancer Patients In Jamaica. Cancer Causes Control. 2017 Jul 15.doi: 10.1007/s10552-017-0924-9.

[8] Mutimanda Dwisatyadini. Pemanfaatan Tanaman Obat Untuk Pencegahan Dan Pengobatan Penyakit Degeneratif. Optimalisasi Peran Sains dan Teknologi untuk Mewujudkan Smart City.

[9] Hasanah SN, Widowati L Jamu PadaPasienTumor/Kanker sebagai Terapi Komplementer Herbal:as A Compelementary Therapy for Tumor /Cancer Patients. Jurnal Kefarmasian Indonesia Vol.6 No.1Feb.2016:49-59.

[10] Sayed S, Zahirmoloo, Ngugi A, Allidina A, Ndumia R., Mutuiri A, Wasike R, Wahome,Dmohamed Abdihakin C.,Kasmani,R., Spears C.D, Oigara R, Elizabeth B, Mwachiro, Satya V.P. Busarla, Kibor K, Ahmed A, Wawire,J, Sherman O, Saleh M, Zujewski J.A, Dawsey S.M. Breast Camps for Awareness and Early Diagnosis of Breast Cancer in Countries With Limited Resources: A Multidisciplinary Model From Kenya. TheOncologist 2016;21:1138-1148.

[11] Sackey H, Hui M, Czene K, Verkooijen H, Edgren G, Frisell $\mathrm{J}$ and Hartman.M. The Impact Of In Situ Breast Cancer And Family History On Risk Of Subsequent Breast Cancer Events And Mortality - A Populationbased Study From Sweden. Breast Cancer Research (2016) 18:105 P.3

[12] Damery S, Gratus C, Grieve R, Warmington $\mathrm{S}$, Jones J, Routledge $\mathrm{P}$, Greenfield S, Dowswell G,Sherriff $\mathrm{J}$ and Wilson $\mathrm{S}$. The Use Of Herbal Medicines By People With Cancer: A Cross-Sectional Survey. British Journal of Cancer (2011) 104, 927 - 933. \& 2011 Cancer Research UK All rights reserved 0007 - 0920/11 www.bjcancer.com

[13] Shim JM. The Influence Of Social Context On The Treatment Outcomes Of Complementary And Alternative Medicine: The Case Of Acupuncture And Herbal Medicine In Japan And The U.S. Globalization and Health (2015) 11:17. DOI 10.1186/s12992-015-0103-2.
[14] Panganai T\&Shumba P. The African Pitocin A Midwife's Dilemma: The Perception Of Women On The Use Of Herbs In Pregnancy And Labour In Zimbabwe, Gweru. Pan African Medical Journal. 2016; 25:9 doi:10.11604/pamj.2016.25.9.7876

[15] Christina J, Abigail W, Cuthbertson LA. Nurses' Knowledge And Attitudes Toward Complementary Therapies For Cancer:A Review Of The Literature. Asia Pac J Oncol Nurs 2016;3:241-51.

[16] Clement YN, Mahase V, Jagroop A, Kissoon K, Maharaj A, Mathura P, Quan CM, Ramadhin D, Mohammed C. Herbal Remedies And Functional Foods Used By Cancer Patients Attending Specialty Oncology Clinics In Trinidad. BMC Complement Altern Med. 2016 Oct 21;16(1):399.

[17] Martin ACBM, Fuzer AM, Becceneri AB, da Silva JA, Tomasin R, Denoyer D, Kim SH, McIntyre KA, Pearson HB, Yeo B, Nagpal A, Ling $X$, Selistre-de-Araújo HS, Vieira PC, Cominetti MR, Pouliot N. [10]-Gingerol Induces Apoptosis And Inhibits Metastatic Dissemination Of Triple Negative Breast Cancer In Vivo. Oncotarget. 2017 Aug 10;8(42):72260-72271

[18] Shareef M, Ashraf MA, Sarfraz M Natural Cures For Breast Cancer Treatment. Saudi Pharm J. 2016 May;24(3):233-40.

[19] Adeyeni TA, Khatwani N, San K, Ezekiel UR. BMI1 is downregulated by the natural compound curcumin, but not by bisdemethoxycurcumin and dimethoxycurcumin.Physiol Rep. 2016 Aug;4(16).

[20] Koprowski S, Sokolowski K, Kunnimalaiyaan S, Gamblin TC, Kunnimalaiyaan M. Curcumin-Mediated Regulation Of Notch1/Hairy And Enhancer of Split1/Survivin: Molecular Targeting In Cholangiocarcinoma. J Surg Res. 2015 Oct;198(2):434-40.

[21] Ali NM, Yeap SK, Abu N, Lim KL, Ky H, Pauzi AZM, Ho WY, Tan SW, Alan-Ong HK, Zareen S, Alitheen NB, Akhtar MN. Synthetic Curcumin Derivative DK1 Possessed G2/M Arrest And Induced Apoptosis Through Accumulation Of Intracellular ROS In MCF-7 Breast Cancer Cells. Cancer Cell Int. 2017 Feb 21;17:30. 
[22] Thongon N, Boonmuen N, Suksen K, Wichit $\mathrm{P}$, Chairoungdua A, Tuchinda P, Suksamrarn A, Winuthayanon $\mathrm{W}^{4}$, Piyachaturawat $\mathrm{P}$. Selective Estrogen Receptor Modulator (SERM)-Like Activities Of Diarylheptanoid, A Phytoestrogen From Curcuma Comosa, In Breast Cancer Cells, Pre-Osteoblast Cells, And Rat Uterine Tissues. J Agric Food Chem. 2017 May 3;65(17):3490-3496.

[23] Amalraj A, Pius A, Gopi S, Gopi S. Biological activities of curcuminoids, other biomolecules from turmeric and their derivatives - A review.J Tradit Complement Med. 2016 Jun 15;7(2):205-233. 